\title{
Genetic variability of captive populations of Rhamdia quelen (Teleostei: Pimelodidae) using microsatellite markers
}

\author{
Marina Virmond ${ }^{1}$ \\ Daniele Conceição ${ }^{1}$ \\ Hilton Amaral Junior ${ }^{2}$ \\ Rodolfo Luis Petersen ${ }^{1 *}$ \\ ${ }^{1}$ Centro de Estudos do Mar, Universidade Federal do Paraná \\ Avenida Beira Mar, s/n, Caixa Postal 61, CEP 83255-900, Pontal do Paraná - PR, Brasil \\ ${ }^{2}$ Epagri, Empresa de Pesquisa Agropecuária de Santa Catarina, Camboriú - SC, Brasil \\ * Autor para correspondência \\ rodolfopetersen@hotmail.com
}

Submetido em 12/04/2017

Aceito para publicação em 26/09/2018

\section{Resumo}

Variabilidade genética de populações cativas de Rhamdia quelen utilizando marcadores microssatélites. A análise da variabilidade genética de populações a serem utilizadas em programas de melhoramento genético é importante para a seleção de uma população base, a qual maximize a divergência genética entre as populações selecionadas. Duas populações cativas de Rhamdia quelen foram analisadas com marcadores microssatélites. Para a amplificação dos loci foram utilizados os seguintes primers marcados com fluoróforos: Pcor1 (FAM), Pcor2 (TET), Pc17 (HEX), Pc97 (TET) e Rh1 (FAM). Os cinco loci de microssatélites analisados apresentaramse altamente polimórficos e informativos, com uma média de 9,8 alelos/locus. O coeficiente de endogamia $\left(\mathrm{F}_{\text {IS }}\right)$ apresentou valores negativos, evidenciando que não houve cruzamentos consanguíneos. $\mathrm{O}$ teste de diferenciação alélica e genotípica entre as duas populações foi estatisticamente significativo, e o valor de divergência genética total $\left(\mathrm{F}_{\mathrm{ST}}\right)$ foi de 0,01939 , indicando baixo nível de divergência genética nas populações. A análise de variância molecular (AMOVA) demonstrou que a maior variabilidade genética se encontra dentro das populações $(98,06 \%)$. Os marcadores microssatélites utilizados foram eficientes para a análise da estrutura e variabilidade genética das populações cativas de Rhamdia quelen. O manejo reprodutivo adotado mostrou-se adequado, uma vez que garantiu a manutenção da variabilidade genética das populações.

Palavras-chave: Endogamia; Jundiá; Piscicultura

\section{Abstract}

The analysis of genetic variability in populations that are candidates for breeding programs is important for selecting a base population, which maximizes genetic divergence. Two captive populations of Rhamdia quelen were analyzed with microsatellite markers. The loci were amplified with fluorophore labelled primers: Pcor1 (FAM), Pcor2 (TET), Pc17 (HEX), Pc97 (TET), and Rh1 (FAM). The five examined microsatellite loci were highly polymorphic and informative with an average of 9.8 alleles/locus. The inbreeding coefficient $\left(\mathrm{F}_{\text {IS }}\right)$ presented negative values indicating that inbreeding did not occur. The allelic and genotypic differentiation tests 
between the two populations showed statistically significant values; the total genetic divergence $\left(\mathrm{F}_{\mathrm{ST}}\right)$ value was 0.01939 , indicating a low level of genetic divergence. The analysis of molecular variance (AMOVA) showed that the highest genetic variability was within (98.06) and not between the populations. The microsatellite markers used were efficient for analyzing the structure and genetic variability in captive populations of Rhamdia quelen. The adopted reproduction management proved to be appropriate because it ensured the maintenance of genetic variability in these populations.

Key words: Jundiá; Pisciculture; Inbreeding

\section{Introduction}

Since its inception, Brazilian fish farming has focused on the production of exotic species, such as tilapia (Oreochromis niloticus) and the common carp (Cyprinus carpio) (ANDRADE; YASUI, 2003; OSTRENSKY et al., 2007), because there is extensive knowledge about the biology and productive management of these species and genetically improved strains. The introduction of native species in production systems is of great interest to producers and researchers because they are well accepted in the consumer market and by environmental oversight institutions, and have a high potential for cultivation. Zootechnical protocols have been developed for the cultivation of certain species; however, management of reproductive populations is still executed in a precarious way because of deficiencies in breeding control in nursery centers, genetic selection programs, and information about the genetic diversity in targeted populations (KOCHER et al., 1998).

The identification and genetic characterization of a species are fundamental for the implementation of genetic improvement programs of captive animals (HILSDORF; KRIEGER, 1998). These programs are based on the knowledge of the genetic variability of organisms, which promotes the selection of breeders with high growth rates and desirable physiological characteristics. Selected individuals are subjected to successive breeding and artificial selection to obtain improved performance in new generations and, consequently, in cultivation. Thus, the identification of genetic variation among and within populations of species that are candidates for breeding programs is of paramount importance for the delimitation of optimal strategies for conservation and management of these species.
Poor zootechnical reproductive management planning with random breeding and intentional artificial selection without a pedigree control can result in changes in genetic diversity (KOCHER et al., 1998). Therefore, breeding between closely related individuals (inbreeding), selection of a small number of actual breeders and their decrease over generations, an uneven proportion of males and females during breeding, and intense application of individual selection are the main reducers of genetic variability in cultivated populations (FALCONER; MACKAY, 1996; SEKINO et al., 2004).

The study of genetic variability in populations was made possible through the development of several molecular markers, especially those based on DNA polymorphism, which allow the variability of any organism to be accessed. With the technological advancements in recent decades, molecular markers have become important tools in studies of population genetics of wild or captive fish populations (O'CONNELL; WRIGHT, 1997).

Microsatellites are considered suitable for genetic diversity studies applied to fishing and fish farming (O'CONNELL; WRIGHT, 1997). Microsatellite markers or SSRs (Simple Sequence Repeats) are sequences of 1 to 6 base pairs (bps) repeated in tandem and found in eukaryotes (LITT; LUTY, 1989; WEBER; MAY, 1989). Microsatellites offer several advantages over other molecular markers, such as abundance and wide-dispersion in the genome of most species, high degree of polymorphism, co-dominance of alleles that allow discrimination between homozygosity and heterozygosity, short fragments, and transferability (cross-amplification) because their loci tend to be evolutionarily conserved in similar species. These characteristics and the multiple alleles of microsatellites result in these markers having greater polymorphism 
information content (FERREIRA; GRATTAPAGLIA, 1998; O’REILLY; WRIGHT, 1995).

The use of microsatellites in fish farming allows the evaluation of cultivated stocks, appropriate management measures for the maintenance of genetic variation and levels of heterozygosity (FERGUSON et al., 1995), and selection of breeders in commercial operations (O’REILLY; WRIGHT, 1995; DE LEON et al., 1998).

Jundiá (Rhamdia quelen) is a freshwater catfish in the family Pimelodidae. The species has a neotropical distribution and occurs from central Argentina to southern Mexico (SILFVERGRIP, 1996). The species is native to southern Brazil and is one of the most promising species for fish farming because of its resistance to low temperatures, rapid growth and good acceptance of commercial rations, amenability to reproduction induction, and high carcass yield with tasty meat and few bones (CARNEIRO et al., 2002; BALDISSEROTTO; NETO, 2004). The history of reproduction of the populations within our study is unknown and does not have a pedigree record. Therefore, we expected low intrapopulation genetic variability because of genetic drift and inbreeding. Genetic improvement can be a very important tool to increase growth rates and make the cultivation of $R$. quelen more commercially attractive. Thus, knowing the genetic diversity of jundiá populations that can be used in breeding programs is essential to scale the initial genetic variability, as well as to set future breeding priorities, thereby increasing selection effectiveness and gains throughout generations. The objective of this study was to use microsatellite markers to evaluate the genetic variability in two captive populations of $R$. quelen that are population base candidates in genetic improvement programs.

\section{Materials and Methods}

\section{Sample collection}

Two captive populations (GASPAR and CAÇADOR strains) from the Camboriú Experimental Breeding
Field - CEPC (Santa Catarina State) in southern Brazil were analyzed. The reproduction and dissemination of fingerlings started in 2006; these populations were analyzed in this study after approximately six generations in captivity. The breeding was randomly performed from one generation to the next, depending on the stage of gonad maturation in females. No selective pressure for specific zootechnical characteristics was applied to the breeders during the six generations.

Fin tissue samples were randomly taken from both strains of adult fish, comprising the reproductive stock populations at CEPC. The tissues were fixed in ethanol and stored in sterile microtubes at $-20^{\circ} \mathrm{C}$.

\section{Sample processing}

\section{DNA extraction and amplification}

DNA was extracted from fin tissue samples of 50 individuals per population according to the NORGEN kit protocol (Biotek Corp.). Five microsatellite primers were used in the PCR reactions: Pcor1, Pcor2 (REVALDAVES et al., 2005), PC17, PC97 (MOESER; BERMINGHAM, 2005), and RH1 (F: 5 '-TTACTCGGGATACGATGC-3' and R: 5 '- TTGTCAGAGTCCAAAGG-3'); these primers were labelled with the FAM, TET, HEX, TET, and FAM fluorophores, respectively. With the exception of RH1, the only microsatellite locus developed and tested for Rhamdia quelen, the other microsatellites loci were originally designed for Pseudoplatystoma corruscans (Table 1). Therefore, cross-amplification was carried out.

The cycling conditions were: one cycle at $94^{\circ} \mathrm{C}$ for 2 minutes, 30 cycles at $95^{\circ} \mathrm{C}$ for 1 minute, one cycle at the annealing temperature specific to each microsatellite primer for 1 minute, one cycle at $72^{\circ} \mathrm{C}$ for 1 minute, and one cycle at $72^{\circ} \mathrm{C}$ for 7 minutes. Each reaction contained 1.25 U of Taq polymerase, $0.1 \mathrm{mM}$ dNTPs, 1X PCR buffer, $0.6 \mu \mathrm{M}$ of each primer (Forward and Reverse), $1.5 \mathrm{mM} \mathrm{MgCl}, 1 \mu \mathrm{L}$ of DNA, and autoclaved Milli-Q water, for a total volume of $10 \mu \mathrm{L}$. 
TABLE 1: Microsatellite motif, PCR primer sequences ( $\left.5^{\prime} \mathrm{X}-3^{\prime} \mathrm{X}\right)$, locus-specific annealing temperature, and GenBank accession number for the five microsatellite loci.

\begin{tabular}{|c|c|c|c|c|}
\hline Locus & Motif & Primer sequences (5'-3') & $\begin{array}{l}\text { PCR annealing } \\
\text { temperature }{ }^{\circ} \mathrm{C}\end{array}$ & GenBank \\
\hline \multirow[t]{2}{*}{ Pcor1 } & $(\mathrm{TC})_{9} \mathrm{GC}(\mathrm{TC})_{9}$ & F: AAACCCGAGGATAACCAGTC & 55.5 & AY737063 \\
\hline & & R: AGCGTGCTACTAACACAAAC & & \\
\hline \multirow[t]{2}{*}{ Pcor2 } & $(\mathrm{AG})_{19}$ & F: GATATGCAAATAAGAAGGTC & 55 & AY737064 \\
\hline & & R: TCTTCTGGCTTTTCCTCCTCT & & \\
\hline \multirow[t]{3}{*}{ PC17 } & $(\mathrm{CA})_{21}$ & F: ACGACGTTGTAAAACGACGC & 59 & AY833371 \\
\hline & & CTGCCAGGTAAATCTGAA & & \\
\hline & & R:AGGTATGCGGAACACTGACC & & \\
\hline \multirow[t]{3}{*}{ PC97 } & $(\mathrm{CA})_{14}$ & F: CACGACGTTGTAAAACGACG & 58 & AY833377 \\
\hline & & TTGGTTTGAGGTCGGTTTG & & \\
\hline & & R: GAACAGTGAGAGCGGAGAC & & \\
\hline \multirow[t]{2}{*}{ RH1 } & - & F: TTACTCGGGATACGATGC & 56 & --- \\
\hline & & R: TTGTCAGAGTGCCAAAGG & & \\
\hline
\end{tabular}

PCR products were analyzed and genotyped using the software Fragment Profiler v. 1.2 (MegaBACE Genetic Profiler; Amersham Biosciences Inc.).

\section{Data processing}

The Genepop program web v. 3.1 (RAYMOND; ROUSSET, 1995) was used for the intrapopulation analyses to calculate the number of observed alleles $\left(\mathrm{N}_{\mathrm{A}}\right)$, allele frequencies, observed heterozygosity $\left(\mathrm{H}_{\mathrm{o}}\right)$, expected heterozygosity $\left(\mathrm{H}_{\mathrm{E}}\right)$, population inbreeding coefficient $\left(\mathrm{F}_{\mathrm{IS}}\right)$, and Hardy-Weinberg equilibrium. The genetic variations between and within the populations (inter- and intrapopulation analysis) and genetic distances $\left(\mathrm{F}_{\mathrm{ST}}\right)$ were identified through and analysis of molecular variance (AMOVA) using the software Alerquin v. 3.1. (EXCOFFIER et al., 2005).

The effective number of alleles per locus was estimated from the expression $A_{e}=1 /\left(1-H_{E}\right)$, where $\mathrm{H}_{\mathrm{E}}$ is the expected heterozygosity value for the analyzed loci. The polymorphic information content (PIC) was calculated according to Botstein et al. (1980). To evaluate the existence of null alleles, the software Microchecker version 2.2.3 was used.

\section{Results}

The five analyzed microsatellite loci showed a high degree of polymorphism. Sixty-seven distinct alleles were detected, including 11 in the Pcor1 locus, 18 in Pcor2, 8 in PC17, 18 in PC97, and 12 in RH1. The analysis for the presence of null alleles did not show evidence of loci in both populations evaluated. The average number of alleles per locus was 9.8 , and the average effective number of alleles was $5.25 \pm 0.9$ in the two studied populations (GASPAR and CAÇADOR) (Table 2). Twelve alleles were exclusive to GASPAR and 7 to CAÇADOR (Table 2).

The $\mathrm{H}_{\mathrm{E}}$ values ranged from 0.612 (PC17 locus) to 0.898 (PC97) in GASPAR and from 0.690 (PC17) to 0.830 (Pcor2) in CAÇADOR. The $\mathrm{H}_{\mathrm{O}}$ values ranged from 0.625 (PC97 in CAÇADOR) to 0.977 (RH1 in GASPAR). The populations were not in Hardy-Weinberg 
equilibrium (HWE), showing significant deviations $(p<0.01)$ in most of the analyzed loci. The $\mathrm{F}_{\text {IS }}$ values were statistically significant for each population considering all loci and for all loci and both populations $(\mathrm{p}<0.01)$ (Table 3).
The average PIC values were 0.776 in GASPAR and 0.734 in CAÇADOR, demonstrating the high informativeness of the five analyzed microsatellite loci (Table 3).

TABLE 2: Allele size, allele frequencies, and private alleles for the two Randhia quelem captive populations.

\begin{tabular}{ccccc}
\hline Locus & Population & Allele size & Allele frequencies & Private alleles \\
\hline PC17 & GASPAR & $239 / 255 / 263$ & $0.09 / 0.54 / 0.29$ & - \\
& CAÇADOR & $239 / 255 / 263$ & $0.14 / 0.51 / 0.14$ & $257 / 256$ \\
PC97 & GASPAR & $264 / 266 / 268 / 278$ & $0.11 / 0.11 / 0.14 / 0.20$ & $289 / 282 / 259 / 270$ \\
& CAÇADOR & $263 / 264 / 266$ & $0.14 / 0.27 / 0.33$ & 280 \\
Pcor1 & GASPAR & $81 / 83 / 85 / 87 / 91$ & $0.14 / 0.26 / 0.30 / 0.15 / 0.07$ & 186 \\
& CAÇADOR & $85 / 87 / 144$ & $0.34 / 0.16 / 0.16$ & $248 / 144$ \\
Pcor2 & GASPAR & $181 / 203 / 207 / 226 / 236$ & $0.11 / 0.14 / 0.21 / 0.12 / 0.10$ & $244 / 217 / 171$ \\
& CAÇADOR & $181 / 213 / 226 / 236$ & $0.26 / 0.28 / 0.10 / 0.10$ & $95 / 224$ \\
RH1 & GASPAR & $118 / 229 / 232$ & $0.43 / 0.21 / 0.18$ & $219 / 103 / 160 / 117$ \\
& CAÇADOR & $118 / 229 / 232$ & $0.46 / 0.15 / 0.25$ & - \\
\hline
\end{tabular}

TABLE 3: Genetic variability indexes obtained from an analysis of variability of the five microsatellite loci: number of animals genotyped per marker $(\mathrm{N})$, number of total and effective alleles per marker per strain (A and $\mathrm{A}_{\mathrm{e}}$ ), observed heterozygosity $\left(\mathrm{H}_{\mathrm{O}}\right)$, expected heterozygosity $\left(\mathrm{H}_{\mathrm{E}}\right)$, probability estimates regarding deviation from Hardy-Weinberg equilibrium $(P)$, polymorphism information content $(\mathrm{PIC})$, and inbreeding coefficient $\left(\mathrm{F}_{\mathrm{IS}}\right)$.

\begin{tabular}{cccccccc}
\hline Population & & Pcor1 & Pcor2 & PC17 & PC97 & RH1 & Mean \\
& $\mathrm{N}$ & 42 & 44 & 43 & 42 & 44 & 43 \\
& $\mathrm{~A}$ & 8 & 15 & 5 & 14 & 10 & 10.4 \\
& $\mathrm{~A}_{\mathrm{e}}$ & 4.860 & 8.850 & 2.570 & 9.813 & 3.790 & 5.977 \\
& $\mathrm{H}_{\mathrm{O}}$ & 0.952 & 0.841 & 0.860 & 0.786 & 0.977 & 0.8832 \\
& $\mathrm{H}_{\mathrm{E}}$ & 0.794 & 0.887 & 0.612 & 0.898 & 0.736 & 0.7854 \\
& $P$ & 0.0037 & 0.0036 & 0.0016 & 0.0000 & 0.0000 & 0.00178 \\
& $\mathrm{PIC}$ & 0.7848 & 0.8770 & 0.6046 & 0.8874 & 0.7283 & 0.77642 \\
& $\mathrm{~F}_{\mathrm{IS}}$ & -0.2010 & 0.0520 & -0.1710 & 0.1260 & -0.3317 & -0.10514 \\
\hline \multirow{6}{*}{ CAÇADOR } & $\mathrm{N}$ & 26 & 30 & 31 & 24 & 32 & 28.6 \\
& $\mathrm{~A}$ & 10 & 10 & 7 & 11 & 8 & 9.2 \\
& $\mathrm{~A}_{\mathrm{e}}$ & 5.820 & 5.870 & 3.220 & 5.030 & 3.320 & 4.652 \\
& $\mathrm{H}_{\mathrm{O}}$ & 0.960 & 0.667 & 0.806 & 0.625 & 0.750 & 0.7616 \\
& $\mathrm{H}_{\mathrm{E}}$ & 0.824 & 0.829 & 0.690 & 0.801 & 0.699 & 0.7686 \\
& $P$ & 0.1661 & 0.000 & 0.7542 & 0.0000 & 0.1071 & 0.20550 \\
& $\mathrm{PIC}_{5}$ & 0.8120 & 0.7061 & 0.6795 & 0.7847 & 0.6884 & 0.73414 \\
& $\mathrm{~F}_{\mathrm{IS}}$ & -0.1625 & 0.1994 & -0.171 & 0.223 & -0.073 & 0.00318 \\
\hline
\end{tabular}


The allelic and genotypic differentiation between the two populations was statistically significant $(\mathrm{p}<0.01)$, considering the four loci together and each locus separately, with the exception of RH1. The highest allele frequencies were similar in both populations (Table 2).

The $\mathrm{F}_{\mathrm{ST}}$ value was 0.01939 indicating a low level of genetic structuring within the populations. The analysis of molecular variance (AMOVA) showed that the highest genetic variability was found within the populations $(98.6 \%)$ and the lowest (1.94 percent) between the populations (Table 4).

TABLE 4: Hierarchical analysis of molecular variance (AMOVA) within and between the examined GASPAR and CAÇADOR populations.

\begin{tabular}{lcc}
\hline \multicolumn{1}{c}{ Source of variation } & $\begin{array}{c}\text { Variance } \\
\text { component }\end{array}$ & $\begin{array}{c}\text { Percentage of } \\
\text { variation (\%) }\end{array}$ \\
\hline $\begin{array}{l}\text { Between groups (Gaspar } \\
\text { vs. Caçador) }\end{array}$ & 2.676 & $1.94 \%$ \\
$\begin{array}{l}\text { Among individuals } \\
\text { within each stock }\end{array}$ & 162.857 & $98.06 \%$ \\
Fixation indices $\left(\mathrm{F}_{\mathrm{ST}}\right)=0.01939$ & \\
\hline
\end{tabular}

\section{Discussion}

The results demonstrate that, although the genetic variability in the studied captive populations is high, there are low levels of genetic differentiation. The microsatellite markers used in this study were powerful tools for the analysis of genetic variability in $R$. quelen populations. The PIC is an indicator of the quality of the molecular marker in genetic studies. According to Botstein et al. (1980), values greater than 0.5 are considered very informative, those between 0.25 and 0.5 are medially informative, and those less than 0.25 are essentially not informative. The average PIC observed in the five microsatellite markers was 0.755 , which indicates that these have high informational power and are effective as genetic markers in $R$. quelen populations. This value is consistent with those published by Ribolli and Zaniboni-Filho (2009) in a study of the same species (0.706), and by Dantas et al. (2013) in studies of $P$. corruscans ( 0.80 and 0.699 , respectively).
The average number of alleles per locus was inferior to those found in natural populations of fish in the family Pimelodidae, such as Pseudoplatystoma corruscans that was analyzed by Pereira et al. (2008). These authors estimated averages of 17 and 15.2 alleles/locus, respectively. Ribolli et al. (2012) observed an average of 15.8 alleles/locus in the catfish Pimelodus maculatus. Ribolli and Zaniboni-Filho (2009) report an average of 6 alleles/locus in $R$. quelen produced in captivity. The number of alleles/locus observed in the GASPAR and CAÇADOR populations was lower than those obtained in natural populations of other species from the same family. The number of effective alleles indicated that many alleles are rare or present in low frequencies. The presence of few alleles with high frequencies may indicate that within the natural populations, from which the first generations were taken to be reproduced under captive conditions, this was already high. The high $\mathrm{H}_{\mathrm{O}}$ values were similar to those observed by Ribolli and Zaniboni-Filho (2009) in breeding stocks of $R$. quelen using the same microsatellite loci (average $\mathrm{H}_{\mathrm{E}}=0.72$ and $\mathrm{H}_{\mathrm{O}}=0.76$ ). Neto (2008) reports heterozygosity values that are different from those expected in P. corruscans populations, representing a loss of genetic variability. The reduction in genetic diversity in cultivation results from reproductive management with a small effective number of breeders and intense individual selection, which leads to the increased number of homozygotes. The results of the estimated heterozygosity in populations of $R$. quelen indicate that either a high effective number $\left(\mathrm{N}_{\mathrm{e}}\right)$ of breeders was present in each generation or that accidental migration of genes may have occurred in the history of these strains. The employed management in the production of matrices over generations without defined selection criteria may have contributed to the maintenance of diversity in the studied populations.

The differences between $\mathrm{H}_{\mathrm{E}}$ and $\mathrm{H}_{\mathrm{O}}$ are always expected in cultivated populations because gene frequency deviations, possibly caused by genetic drift and inbreeding, tend to increase throughout generations (ROMANA-EGUIA et al., 2004). Most of the studied loci showed significant deviation from the HardyWeinberg equilibrium (HWE). These deviations cannot be attributed to inbreeding because the average value of $F_{\text {IS }}(-0.05098)$ was low and negative, ruling out the 
possibility of inbreeding. Lopera-Barreto et al. (2010) observed an average $\mathrm{F}_{\mathrm{IS}}$ of -0.358 in captive populations of P. mesopotamicus, and Dantas et al. (2013) found mean values of 0.045 and 0.034 in P. corruscans, respectively. However, an increase in inbreeding is common and expected, especially in populations with reproduction management without a pedigree control. Several studies show significant HWE deviations caused by an excessive number of homozygotes that result from inbreeding. Pereira et al. (2008) observed high values of $\mathrm{F}_{\text {IS }}(0.176)$ in populations of $P$. corruscans. Thus, endogamy indexes are directly related to the management adopted in cultivation. The HWE deviation caused by the obtained values of the excessive number of heterozygotes and low $\mathrm{F}_{\text {IS }}$ could be explained by accidental introductions of individuals of the same species from other populations while in captivity. The unidirectional gene flow from one population to another increases the likelihood of the incorporation of new alleles and decreases the $\mathrm{F}_{\text {IS }}$. The presence of a significant number of exclusive alleles in each population strengthens this hypothesis.

According to the classification of Wright (1978), the $\mathrm{F}_{\mathrm{ST}}$ value obtained in this study was low and significant, which is evidence of reduced genetic differentiation between the GASPAR and CAÇADOR populations. The analysis of molecular variance (AMOVA) showed that the highest genetic variation was within the populations whereas the variation between them was very low. The genotype and allelic frequencies showed statistically significant differences; however, most of the most frequent alleles were shared by both populations. The GASPAR and CAÇADOR populations are cultivated in the same experimental farm under the same environmental parameters. The trend of increased frequency of the same alleles could indicate similar selection pressures applied to both populations, leading them to increased genetic homogeneity overtime.

The results obtained demonstrate that the populations showed low levels of genetic differentiation between them, but high levels within each population. Lidani et al. (2006) described 8 polymorphic loci using the PCR-RAPD technique and observed increased levels of genetic variability in captive stocks. There are no publications that we are aware of in the scientific literature that describe the genetic variability of $R$. quelen in native stocks with molecular markers.

The microsatellite markers used in this study proved to be efficient tools to analyze the structure and genetic variability in populations of $R$. quelen.

\section{Acknowledgements}

The authors thank the Conselho Nacional de Desenvolvimento Científico e Tecnológico (CNPq) for the project funding and scholarships, and Prof. Dr. Paulo da Cunha Lana from the Centro de Estudos do MarUFPR for financing the translation of this manuscript.

\section{References}

ANDRADE, D. R.; YASUI, G. S. O manejo da reprodução natural e artificial e sua importância na produção de peixes no brasil. Revista Brasileira de Reprodução Animal, Belo Horizonte, v. 27, p. 166-172, 2003.

BALDiSSEROTTO, B.; NETO, J. R. Criação de jundiá. Santa Maria: Editora UFSM, 2004. 232 p.

BOTSTEIN, D.; WHITE, R. P.; SKOLNICK, M.; DAVIS, R. W. Construction of a genetic linkage map in man using restriction fragment length polymorphisms. American Journal of Human Genetics, Houston, v. 32, p. 314-331, 1980.

CARNEIRO, P. C.; BENDHACK, F.; MILKOS, J. D.; SCHORER, M.; OLIVERA FILHO, P. R C. Jundiá: um grande peixe para a Região Sul. Panorama da Aquicultura, Rio de Janeiro, v. 12, p. 41-46, 2002.

DANTAS, H. L.; dos SANTOS, N.; ARCANJO, M.; OLIVEIRA, K.; CAVALCANTI, K.; SEVERI, W. I.; DINIZ, F.; COIMBRA, M. R M. Genetic diversity of captive and wild threatened catfish Pseudoplatystoma corruscans in the São Francisco River. Reviews in Fisheries Science, Philadelphia, v. 21, p. 237-246, 2013.

DE LEON, F. J. G.; CANONN, M.; QUILLET, E.; BONHOMME, F.; CHATAIN, K. The application of microsatellite markers to breeding programmes in the sea bass, Dicentrarchus labrax. Aquaculture, Amsterdam, v. 159, p. 303-316, 1998.

EXCOFFIER, L.; LAVAL, G.; SCHENEIDER, S. Arlequin v. 3.1.1: an integrated software package for population genetics data analysis. Evolutionary Bioinformatics, Cambridge, v. 1, p. 47-50, 2005.

FALCONER, D. S.; MACKAY, T. F. C. Introduction to quantitative genetics. 4 ed. Edinburgh: Longman Group Limited, 1996. 464 p.

FERGUNSON, A.; TAGGART, J. B.; PRODOLH, P. A.; MCMEEL, O.; THOMPSON, C.; STONE, C.; McCGINNITY, P.; HYNES, R. A. The application of molecular markers to the study and conservation of fish populations, with special reference to Salmo. Journal of Fish Biology, Malden, v. 47, p. 103-126, 1995. 
FERREIRA, M. E.; GATTAPAGLIA, D. Introdução ao uso de marcadores moleculares em análise genética. 3. ed. Brasília: Embrapa-Cenargen, 1998. 220 p.

HILSDORF, A.; KRIEGER, J. E. Biologia molecular na conservação de peixes: ferramentas moleculares e conservação genética. Biotecnologia Ciência e Desenvolvimento, Natal, v. 1, p. 10-12, 1998.

KOCHER, T. D.; LEE, W. J.; SOBOLEWSKA, H.; PENMAN, D.; MCANDREW, B. A genetic linkage map of a cichlid fish, the tilapia (Oreochromis niloticus). Genetics, Pittsburgh, v. 148, p. 1225-1232, 1998.

LIDANI, K. C. F.; LIMA, J. R.; TORRES, R. A.; GABRIEL, J. E.; MADEIRA, H. M. F.; CARNEIRO, P. C. F. Variabilidade genética de um estoque cativo de jundiá (Rhamdia quelen). Revista Acadêmica, Curitiba, v. 4, n. 3, p. 47-53, 2006.

LITT M.; LUTY J. A hypervariable microsatellite revealed by in vitro amplification of a dinucleotide repeat within the cardiac muscle actin gene. American Journal of Human Genetics, Houston, v. 44, p. 39-40, 1989.

LINDARI, C. F.; LIMA, J. R; TORRES, R.A.; GABRIEL, J. A.; MADEIRA, H. M. F. Variabilidade genética de um estoque cativo de jundiá (Rhamdia quelen) Rev. Acad., Curitiba, v.4, n.3, p. 4753, 2006.

LOPERA-BARRERO, N. M.; RIBEIRO, R.P.; POVH, J.A.; SIROL, R. N.; MANGOLIN, C. A. Genetic Evaluation of pacu (Piaractus mesopotamicus) natural populations and from the broodstocks of a stock enhancement program using microsatellite markers. Arquivo Brasileiro de Medicina Veterinária e Zootecnia, Belo Horizonte, v. 62, p. 954-963, 2010.

NETO, M. A. Avaliação genética do estoque fundador de surubim, Pseudoplatystoma corruscans (Spix \& Agassiz, 1829), para o repovoamento do submédio rio São Francisco. Dissertação (Mestrado em Recursos Pesqueiros e Aquicultura) Universidade Federal Rural de Pernambuco, Recife. 2008.

O'CONNELL, P.; WRIGHT, J. M. Microsatellite DNA in fishes. Reviews in Fish Biology and Fisheries, Washington, v. 7, p. 331363, 1997.

O'REILLY, P.; WRIGHT, J. M. The evolving technology of DNA fingerprinting and its application to fisheries and aquaculture. Journal of Fish Biology, Malden, v. 47, p. 29-55, 1995.
OSTRENSKY, A.; BORGHETTI, J. R.; SOTO, D. Estudo setorial para consolidação de uma aquicultura sustentável no Brasil. Curitiba: Grupo Integrado de Aquicultura e Estudos Ambientais, 2007. 279 p.

PEREIRA, L. H. G.; FORESTI, F.; OLIVEIRA, C. Genetic structure of the migratory catfish Pseudoplatystoma corruscans (Siluriformes: Pimelodidae) suggests homing behavior. Ecology of Freshwater Fish, Malden, v. 18, p. 215-225, 2008.

RAYMOND, M.; ROUSSET, F. Genepop (version 1.2): population genetics software for exact tests and ecumenicism. Journal of Heredity, Oxford, v. 86, p. 248-249, 1995.

REVALDADES, E.; PEREIRA, L. H. G.; FORESTI, F.; OLIVEIRA, C. Isolation and characterization of microsatellite loci in Pseudoplatystoma corruscans (Siluriformes: Pimelodidae) and cross-species amplification. Molecular Ecology Notes, Weinheim, v. 5, p. 463-465, 2005.

RIBOLLI, J.; MELO, M. R.; ZANIBONI-FILHO, E. Genetic characterization of the Neotropical catfish (Pimelodidae, Siluriformes) in the Upper Uruguay River. Genetics and Molecular Biology, Ribeirão Preto, v. 35, p. 761-769, 2012.

RIBOLLI, J.; ZANIBONI-FILHO, E. Individual contributions to pooled-milt fertilizations of silver catfish Rhamdia quelen. Neotropical Ichthyology, Maringá, v. 7, p. 629-634, 2009.

ROMANA-EGUIA, M. R. R.; IKEDA, M.; BASIAO, Z. U.; TANIGUCHI, N. Genetic diversity in farmed Asian Nile and red hybrid tilapia stocks evaluated from microsatellite and mitochondrial DNA. Aquaculture, Amsterdam, v. 236, p. 131-150, 2004.

SEKINO, M.; SUGAYA, T.; HARA, M.; TANIGUCHI, N. Relatedness inferred from microsatellite genotypes as a tool for broodstock management of Japanese flounder Paralichthys olivaceus. Aquaculture, Amsterdam, v. 233, p. 163-172, 2004.

WEBER, Z.; MAY, P. E. Abundant class of human DNA polymorphism which can be typed using the polymerase chain reaction. American Journal of Human Genetics, Houston, v. 44, p. 388-396, 1989.

WRIGHT S. Evolution and Genetics of Populations. Chicago: University of Chicago, 1978. 511 p. 